\title{
The Implementation Of The Epstein's Model As A Partnership Framework At Saudi Kindergartens
}

Nahla M. Gahwaji, King Abdulaziz University, Saudi Arabia

\begin{abstract}
The aim of the study is to reveal the implementation of a partnership framework at Saudi kindergartens in accordance to the Epstein's Model which is considered from the perceptions of Kindergartens' female teachers. Analytical descriptive methodology was employed, and the study sample included 48 public kindergartens' teachers and 44 private kindergartens' teachers in Jeddah city, Saudi Arabia. The study tools included a questionnaire that was related to the six fields of Epstein's Model including; parenting, communicating, volunteering, learning at home, decision making, and collaborating with community. The results revealed that implementation of a partnership framework at Saudi kindergartens in accordance to the Epstein's Model were overall average. There were no statistically significant differences between the means of implementing partnership's frameworks in Saudi Arabian kindergartens with its six fields, which attributed to the specific type of Kindergarten (Public-Private). The significant recommendation of the study is formulating partnerships between community institutions and kindergartens to arrange recreational, educational and social programs after school hours, which would be beneficial for children and their families.
\end{abstract}

Keywords: Implementation; Partnership Framework; Saudi Kindergartens; Epstein’s Model

\section{INTRODUCTION}

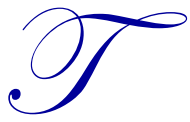

he kindergarten phase is an important educational stage in the life of a child that requires combined efforts of the kindergarten teachers and families to provide proper education to the child. The child's education is a basic process that is not only school's responsibility as an educational institution, but the family also plays an important role in it (Peters, 2015). At this stage, the child moves from the quiet domestic atmosphere to the school environment, which includes individuals, activities, and rules. Therefore, it requires the high capacity of the kindergarten teacher to support partnership programs with the family to strengthen the relationship and exchange of advice and experience to complement each other's work (Langford, Di Santo, Valeo, Underwood \& Lenis, 2018).

Teacher preparation programs and professional development programs must be strengthened in partnership to train the teachers (Nusseirat \& Biygautane, 2012). Parental activities also reduce the behavioural problems of the children. There is a significant impact of support of the families and their participation in activities taking place in the kindergarten (Desforges \& Abouchaar, 2003). The enrolment of children in kindergartens is supported through family discussion and cooperation with them by conducting workshops to the family to improve child's well-being. Kindergartens are important with a strong range of institutions (religious, recreational, corporate, and library) that are linked to maintain stability, cohesion, and well-being of the community. It also helps in expanding and strengthening social networks for children (Eisenhower, Baker \& Taylor, 2016).

The organizational chart for kindergartens in the Ministry of Education in Saudi Arabia is limited to community participation, volunteering, and communicating with parents; although, partnership programs are implemented in many countries around the world including the Kingdom of Saudi Arabia (Organizational Guide for Kindergartens, 2014). In accordance with the vision of the Kingdom of Saudi Arabia 2030, a major objective to involve $80 \%$ of the families in school activities by 2020 is included. The standard of interaction with educators and community has been included within the professional standards of teachers Vision 2030. It is important for the kindergarten teacher to apply 
the concept of partnership as a priority because of the nature of the transition from home to the kindergarten environment. Therefore, the present study aims to identify the fields of partnership in the light of the Epstein's model. The study has recognized the reality of the implementation of partnership frameworks in the light of the Epstein's model from the point of view of female kindergarten teachers. The study's aim has been fulfilled by detecting statistically significant differences $(\mathrm{p}<0.05)$ between the average degree of implementation of partnership frameworks in the light of the Epstein's model of. It has also investigated the obstacles regarding the implementation of partnership frameworks in Saudi kindergartens in the light of Epstein's model.

\section{Epstein's Model}

Epstein's model provides a comprehensive perspective and framework for the partnership, in which each field includes examples of practices and challenges that may be faced by the students, parents, and teachers (Epstein, 2013). This model provides a comprehensive perspective and an integrated framework in the fields of partnership that include parenting, communicating, volunteering, decision-making, learning at home, and collaborating with the community. The Epstein's model is one of the most popular models of partnership and is considered as a comprehensive model. It contains six main fields that activate the partnership in kindergarten (Epstein et al. 2018):

1. Parenting helps all families understand the growth of children and adolescents and create home environments that support child's learning.

2. Communicating is the design and conduct of effective two-way communication about educational programs and the development of children.

3. Volunteering in the recruitment and organization of assistance and support for educational programs and student activities.

4. Making involves the family in making household decisions concerning children and their activities in kindergarten.

5. Learning at home is to provide information and ideas to families regarding ways to help learning at home with children.

6. Collaborating with the community is to identify and integrate resources and services to promote and support children and their families.

The study results will be significant as it has adopted a global and standardized reference to activate the partnership of the Kindergarten teacher through the Epstein's model in Saudi context. It would also help in achieving the objectives of Vision 2030 of Saudi Arabia through involving $80 \%$ of parents at school activities by 2020. It is important to identify the fields of partnership in the Ministry of Education, both within and outside the Kindergarten in the light of Epstein's model. Moreover, it has provided a theoretical framework to deal with the partnership in kindergartens for specialists and researchers in the early childhood stage. The problem of the study can therefore be framed in the following main questions;

1. What is the reality of the implementation of partnership frameworks in Saudi kindergartens in accordance to the Epstein's model?

2. What is the reality of implementation the partnership fields at the Saudi kindergartens in accordance to the Epstein's model from the teachers' perspectives?

3. Are there any statistically significant differences between the average degrees of implementations of the partnership framework and the Saudi kindergarten teachers' perspectives attributed to the type of kindergarten (public or private)?

\section{MATERIAL AND METHODS}

\section{Study Design}

The present study has employed descriptive analytical method to reveal the implementation of a partnership framework at Saudi kindergartens in accordance to Epstein's Model. 


\section{Study Participants}

The study sample included 48 public Kindergartens' female teachers and 44 private Kindergartens' female teachers in Jeddah city.

\section{Data Collection}

Questionnaire has been used as study tool that helped in investigating the reality of the implementation of a partnership framework in accordance to the Epstein's model from kindergarten teachers' perspective. The questionnaire helped to uncover the implementation of a partnership framework at Saudi kindergartens relating to the different fields of Epstein's Model that include; parental, communicating, volunteering, learning at home, decision making, and collaboration with community. The questionnaires were distributed among the teachers recruited from different schools. The questionnaire comprised of two parts: Part 1 that contains demographic data and Part II that includes six fields of partnership, which relate to the reality of the implementation of the partnership framework in accordance to the Epstein's model, from the points of view of kindergarten teachers consisting of 56 statements divided into six fields; Parenting, Communicating, Volunteering, Learning at home, Decision making, and Collaborating with the community consists of 8 statements.

\section{Data Analysis}

The results obtained through analyzing the questionnaire data using Statistical Package of Social Sciences (version 20.0).

\section{RESULTS AND DISCUSSION}

The study has calculated the arithmetical mean and the standard deviations of each field to reveal the implementation of partnership frameworks in accordance to the Epstein's model.

To determine the degree of the kindergarten practices of teachers for family partnership in the field of parenting, there were (8) statements. Table 1 has clearly shown the reality of the Kindergarten practices of family partnership in the field of parenting with an average of 3.57. This value was the average of the fourth category of the five-dimensional Likert scale (3.40 to 4.19) and indicated a high rating. The results showed that there was a discrepancy in the agreement of the sample of the study in terms of kindergarten practices in the field of parenting. The average of the agreement from the sample on the terms ranged from (2.57 to 4.09 out of 5), ranging between the third and fourth categories of the Likert scale and referring to medium and high rating, respectively. The statement "providing clear and useful information to families on the development of child skills" was ranked first with a high rating and this result was consistent with the results of the study conducted by Nitecki (2015). 
Table 1. Mean and standard deviations of the responses of study sample on the field of parenting

\begin{tabular}{|c|c|c|c|c|c|}
\hline Ranking & Measure & $\begin{array}{l}\text { Arithmetic } \\
\text { Mean }\end{array}$ & $\begin{array}{c}\text { Percentage } \\
\%\end{array}$ & $\begin{array}{l}\text { Standard } \\
\text { Deviation }\end{array}$ & Evaluation \\
\hline 1 & $\begin{array}{l}\text { Provides clear and useful information to } \\
\text { families about the development child's skills }\end{array}$ & 4.09 & $77 \%$ & 1.023 & Occurs frequently \\
\hline 2 & $\begin{array}{l}\text { It respects the cultural diversity of kindergarten } \\
\text { children and their families }\end{array}$ & 3.97 & $74 \%$ & 1.218 & Occurs frequently \\
\hline 3 & $\begin{array}{l}\text { Inquire from families about the talents and } \\
\text { strengths of the child }\end{array}$ & 3.82 & $70 \%$ & 1.109 & Occurs frequently \\
\hline 4 & $\begin{array}{l}\text { Provide preparation program to the child and } \\
\text { family in kindergarten }\end{array}$ & 3.74 & $68 \%$ & 1.358 & Occurs frequently \\
\hline 5 & $\begin{array}{l}\text { Provides family ideas and advice on creating a } \\
\text { home environment to support self-learning for } \\
\text { the child }\end{array}$ & 3.53 & $63 \%$ & 1.235 & Occurs frequently \\
\hline 6 & $\begin{array}{l}\text { Assistance is provided to families upon request } \\
\text { or need, directly or indirectly }\end{array}$ & 3.47 & $62 \%$ & 1.354 & Occurs frequently \\
\hline 7 & $\begin{array}{l}\text { Provides information to families on the stages } \\
\text { of child development and electronic } \\
\text { publications }\end{array}$ & 3.41 & $60 \%$ & 1.251 & Occurs frequently \\
\hline 8 & $\begin{array}{l}\text { Provide preparation programs to child and } \\
\text { family to facilitate the transition to primary } \\
\text { school (e.g., a visit to the child with his or her } \\
\text { family to the school to which he intends to } \\
\text { move) }\end{array}$ & 2.57 & $39 \%$ & 1.470 & $\begin{array}{l}\text { No specific pattern } \\
\text { of occurrence }\end{array}$ \\
\hline \multicolumn{2}{|c|}{$\begin{array}{l}\text { The practices of family partnership in the field of parenting } \\
\text { as a whole }\end{array}$} & 3.57 & $64 \%$ & 0.919 & High \\
\hline
\end{tabular}

To determine the degree of the reality of kindergarten practices of family partnership in the field of communicating (15) statements were used. The results have been depicted in Table 2 , showing the reality of the kindergarten practices for family partnership in the field of communicating with an average of 3.71 out of 5 . The results indicated that there is a difference in the agreement of the study sample in terms of kindergarten practices for family partnership in the field of communicating. The average of the agreement of the study sample on the terms ranged from (2.78 to 4.52 out of 5), for the third and fifth categories of the Likert scale.

It has been revealed that contact with the families of children was high in the case of academic, behavioral, or health problems). Majority of the statements have a high rating due to the importance of communicating with families of children. Development of communication means suitable for families with special needs (e.g., children with reading and writing difficulties) was low in rating may be due to the lack of knowledge regarding the child's status. 
Table 2. Mean and standard deviations of the responses of study sample on the field of communicating

\begin{tabular}{|c|c|c|c|c|c|}
\hline Ranking & Measure & $\begin{array}{l}\text { Arithmetic } \\
\text { Mean }\end{array}$ & $\begin{array}{c}\text { Percentage } \\
\%\end{array}$ & $\begin{array}{l}\text { Standard } \\
\text { Deviation }\end{array}$ & Evaluation \\
\hline 1 & $\begin{array}{l}\text { Communicates with families of children when } \\
\text { any academic / behavioral / health problems } \\
\text { arise }\end{array}$ & 4.52 & $88 \%$ & 0.870 & Occurs intensively \\
\hline 2 & $\begin{array}{l}\text { Ensure that correspondence and written and oral } \\
\text { communications are clear }\end{array}$ & 4.14 & $79 \%$ & 1.095 & Occurs frequently \\
\hline 3 & $\begin{array}{l}\text { A council of mothers is held at least once a } \\
\text { semester }\end{array}$ & 4.12 & $78 \%$ & 1.147 & Occurs frequently \\
\hline 4 & $\begin{array}{l}\text { Plans to apply methods of communication with } \\
\text { families of children }\end{array}$ & 4.03 & $76 \%$ & 1.172 & Occurs frequently \\
\hline 5 & $\begin{array}{l}\text { Teachers teach about the value of partnership } \\
\text { and communication with families }\end{array}$ & 3.86 & $71 \%$ & 1.331 & Occurs frequently \\
\hline 6 & $\begin{array}{l}\text { Develop methods of communication with } \\
\text { families of children on a regular basis }\end{array}$ & 3.85 & $71 \%$ & 1.249 & Occurs frequently \\
\hline 7 & $\begin{array}{l}\text { Develop policies requiring the teacher to } \\
\text { communicate periodically with families }\end{array}$ & 3.85 & $71 \%$ & 1.317 & Occurs frequently \\
\hline 8 & $\begin{array}{l}\text { Provide documented information on the } \\
\text { assessment and development of the child's } \\
\text { growth and behavior }\end{array}$ & 3.79 & $70 \%$ & 1.182 & Occurs frequently \\
\hline 9 & $\begin{array}{l}\text { Encourage families to communicate } \\
\text { electronically with teachers }\end{array}$ & 3.63 & $66 \%$ & 1.503 & Occurs frequently \\
\hline 10 & $\begin{array}{l}\text { Child files are sent weekly or monthly and } \\
\text { comments/recommendations from family } \\
\text { awaited }\end{array}$ & 3.59 & $65 \%$ & 1.415 & Occurs frequently \\
\hline 11 & $\begin{array}{l}\text { Awareness leaflets are issued on a regular basis, } \\
\text { including information on kindergarten, local } \\
\text { events, and education tips }\end{array}$ & 3.52 & $63 \%$ & 1.355 & Occurs frequently \\
\hline 12 & $\begin{array}{l}\text { Two-way channels are used to communicate } \\
\text { with the family }\end{array}$ & 3.37 & $59 \%$ & 1.373 & $\begin{array}{l}\text { No specific pattern } \\
\text { of occurrence }\end{array}$ \\
\hline 13 & $\begin{array}{l}\text { Conducts an annual survey to measure the level } \\
\text { of satisfaction for families from kindergarten }\end{array}$ & 3.35 & $59 \%$ & 1.515 & $\begin{array}{l}\text { No specific pattern } \\
\text { of occurrence }\end{array}$ \\
\hline 14 & Advisory sessions are held for new families & 3.24 & $56 \%$ & 1.485 & $\begin{array}{l}\text { No specific pattern } \\
\text { of occurrence }\end{array}$ \\
\hline 15 & $\begin{array}{l}\text { Develop means of communication suitable for } \\
\text { families with special needs (e.g., children with } \\
\text { reading and writing problems) }\end{array}$ & 2.78 & $45 \%$ & 1.630 & $\begin{array}{l}\text { No specific pattern } \\
\text { of occurrence }\end{array}$ \\
\hline \multicolumn{2}{|c|}{$\begin{array}{l}\text { The practices of family partnership in the field of } \\
\text { communicating as a whole }\end{array}$} & 3.71 & $68 \%$ & 0.895 & High \\
\hline
\end{tabular}

The questionnaire included (8) statements to determine the degree of kindergarten practices for family partnership in the field of volunteering as shown in Table 3. It is clear from Table 3 that the reality of the Kindergarten practices of family partnership in the field of volunteering was average (3.02).

The results indicated that there was a difference in the agreement of the study sample in terms of kindergarten practices for family partnership concerning the field of volunteering. In this regard, the average of agreement ranged from 2.38 to 3.50 out of 5 . The high rating indicated the encouragement of families and community institutions led to their interaction with kindergarten to provide voluntary services. Similarly, a study conducted by Sultan (2015) was concerned with lack of mechanisms for dealing with volunteers and the lack of awareness of the importance of investing volunteers in a correct manner. Majority of the statements were of a moderate rating due to the lack of authority that allows the kindergarten to involve families in the field of volunteering. 
Table 3. Mean and standard deviations of the responses of study sample on the field of volunteering

\begin{tabular}{|c|c|c|c|c|c|}
\hline Ranking & Measure & $\begin{array}{l}\text { Arithmetic } \\
\text { Mean }\end{array}$ & $\begin{array}{l}\text { Percentag } \\
\text { e } \\
\%\end{array}$ & $\begin{array}{l}\text { Standard } \\
\text { Deviation }\end{array}$ & Evaluation \\
\hline 1 & $\begin{array}{l}\text { Families and community institutions are } \\
\text { encouraged to provide voluntary services to the } \\
\text { kindergarten }\end{array}$ & 3.50 & $63 \%$ & 1.395 & Occurs frequently \\
\hline 2 & $\begin{array}{l}\text { The participants in the volunteer services are } \\
\text { honored by both time and effort }\end{array}$ & 3.42 & $61 \%$ & 1.462 & Occurs frequently \\
\hline 3 & $\begin{array}{l}\text { Our school explores the interests of families and } \\
\text { their suggestions to participate in various } \\
\text { volunteer fields annually }\end{array}$ & 3.37 & $59 \%$ & 1.396 & $\begin{array}{l}\text { No specific pattern } \\
\text { of occurrence }\end{array}$ \\
\hline 4 & $\begin{array}{l}\text { Reconcile the needs of the Kindergarten with } \\
\text { the proposed volunteer areas of families }\end{array}$ & 3.32 & $58 \%$ & 1.358 & $\begin{array}{l}\text { No specific pattern } \\
\text { of occurrence }\end{array}$ \\
\hline 5 & $\begin{array}{l}\text { Provides a venue for meetings of volunteers and } \\
\text { families }\end{array}$ & 2.83 & $46 \%$ & 1.531 & $\begin{array}{l}\text { No specific pattern } \\
\text { of occurrence }\end{array}$ \\
\hline 6 & $\begin{array}{l}\text { Establishes a flexible volunteer schedule to } \\
\text { enable volunteering from the working families }\end{array}$ & 2.79 & $45 \%$ & 1.411 & $\begin{array}{l}\text { No specific pattern } \\
\text { of occurrence }\end{array}$ \\
\hline 7 & $\begin{array}{l}\text { Provides services to volunteers from families } \\
\text { that provide care for their children }\end{array}$ & 2.52 & $38 \%$ & 1.530 & Occurs sometimes \\
\hline 8 & $\begin{array}{l}\text { Trained volunteers from families to invest time } \\
\text { to increase productivity and effectiveness }\end{array}$ & 2.38 & $35 \%$ & 1.496 & Occurs sometimes \\
\hline \multicolumn{2}{|c|}{$\begin{array}{l}\text { The practices of family partnership in the field of } \\
\text { volunteering as a whole }\end{array}$} & 3.02 & $50 \%$ & 1.161 & Medium \\
\hline
\end{tabular}

The degree of the reality of kindergarten practices concerning family partnership in the field of learning at home was determined by assigning (6) statements. Table 4 revealed an average of 3.57 out of 5 . The results indicated that there is a difference in the agreement of the study sample in terms of kindergarten practices concerning family partnership in the field of learning at home. Here, the average of the agreement of the study sample ranged from 2.99 to 4.39 out of 5 .

Table 4. Mean and standard deviations of the responses of study sample on the field of learning at home

\begin{tabular}{l|l|c|c|c|c}
\hline Ranking & \multicolumn{1}{|c}{ Measure } & \multicolumn{1}{|c}{$\begin{array}{c}\text { Arithmetic } \\
\text { Mean }\end{array}$} & $\begin{array}{c}\text { Percentage } \\
\%\end{array}$ & $\begin{array}{c}\text { Standard } \\
\text { Deviation }\end{array}$ & Evaluation \\
\hline 1 & $\begin{array}{l}\text { Provide family information regarding the } \\
\text { module applied in the program }\end{array}$ & 4.39 & $85 \%$ & 0.877 & Occurs intensively \\
\hline 2 & $\begin{array}{l}\text { Suggest educational activities that can be } \\
\text { carried out by the child at home }\end{array}$ & 3.58 & $64 \%$ & 1.260 & Occurs frequently \\
\hline 3 & $\begin{array}{l}\text { Examples of questions are discussed with the } \\
\text { families to promote the concepts of } \\
\text { educational unit among the children }\end{array}$ & 3.54 & $64 \%$ & 1.313 & Occurs frequently \\
\hline 4 & $\begin{array}{l}\text { Provides ideas for various activities that can } \\
\text { be applied at home to support the objectives } \\
\text { of the educational unit }\end{array}$ & 3.50 & $63 \%$ & 1.288 & Occurs frequently \\
\hline 5 & $\begin{array}{l}\text { Ask the child to create a model of his own at } \\
\text { home }\end{array}$ & 3.43 & $61 \%$ & 1.286 & Occurs frequently \\
\hline 6 & $\begin{array}{l}\text { Some books and stories are suggested for } \\
\text { families to read and discuss with the child }\end{array}$ & 2.99 & $50 \%$ & 1.379 & $\begin{array}{l}\text { No specific pattern } \\
\text { of occurrence }\end{array}$ \\
\hline \multicolumn{2}{l}{ Practices family partnership in learning at home as a whole } & 3.57 & $64 \%$ & 0.984 & High \\
\hline
\end{tabular}

The researcher assigned (11) statements to determine the degree of kindergarten practices concerning family partnership in the field of decision-making and the results have been depicted in Table 5. The reality of the kindergarten practices concerning family partnership in the field of decision-making from teacher's viewpoint achieved an average of 2.45 out of 5 . This is the average of the second category of the five-dimensional Likert scale ranging from 1.80 to 2.59 , indicating low rating. 
The results proved that there was a difference in the practices of kindergarten concerning family partnership in the field of decision making, where the agreement average ranged from 1.82 to 3.66. It is related to the second and fourth categories of Likert scale. It has been explained that the statement "dealing with conflicts and problems of families in an open and respectful manner" is a key partner. These results agreed with Rattray and Jones (2007), who stated that decision-making either relate to academic and behavioral aspects or school activities.

Table 5. Mean and standard deviations of the responses of study sample on the field of decision making

\begin{tabular}{|c|c|c|c|c|c|}
\hline Ranking & Measure & $\begin{array}{l}\text { Arithmetic } \\
\text { Mean }\end{array}$ & $\begin{array}{c}\text { Percentage } \\
\%\end{array}$ & $\begin{array}{l}\text { Standard } \\
\text { Deviation }\end{array}$ & Evaluation \\
\hline 1 & $\begin{array}{l}\text { Deal with family conflicts and problems } \\
\text { openly }\end{array}$ & 3.66 & $67 \%$ & 1.361 & Occurs frequently \\
\hline 2 & $\begin{array}{l}\text { A council of teachers and representatives of } \\
\text { families shall be established to participate in } \\
\text { the process of decision making }\end{array}$ & 2.84 & $46 \%$ & 1.328 & $\begin{array}{l}\text { No specific pattern } \\
\text { of occurrence }\end{array}$ \\
\hline 3 & $\begin{array}{l}\text { Involve families in decision-making related to } \\
\text { the development and improvement of } \\
\text { kindergarten }\end{array}$ & 2.70 & $42 \%$ & 1.381 & $\begin{array}{l}\text { No specific pattern } \\
\text { of occurrence }\end{array}$ \\
\hline 4 & $\begin{array}{l}\text { Provide channels of communication between } \\
\text { families and their representatives }\end{array}$ & 2.64 & $41 \%$ & 1.494 & $\begin{array}{l}\text { No specific pattern } \\
\text { of occurrence }\end{array}$ \\
\hline 5 & $\begin{array}{l}\text { Involving teachers and families in discussing } \\
\text { educational issues and making necessary } \\
\text { decisions }\end{array}$ & 2.61 & $40 \%$ & 1.497 & $\begin{array}{l}\text { No specific pattern } \\
\text { of occurrence }\end{array}$ \\
\hline 6 & $\begin{array}{l}\text { Allows family representatives to communicate } \\
\text { with other less-active families to devise some } \\
\text { ideas and report on them }\end{array}$ & 2.36 & $34 \%$ & 1.472 & Occurs sometimes \\
\hline 7 & $\begin{array}{l}\text { Involve families in the planning and } \\
\text { development of educational units for children }\end{array}$ & 2.25 & $31 \%$ & 1.388 & Occurs sometimes \\
\hline 8 & Involve families in the teacher's calendar & 2.23 & $31 \%$ & 1.483 & Occurs sometimes \\
\hline 9 & $\begin{array}{l}\text { Involve families in planning the daily } \\
\text { kindergarten program }\end{array}$ & 2.02 & $26 \%$ & 1.342 & Occurs sometimes \\
\hline 10 & $\begin{array}{l}\text { Family training workshops for the } \\
\text { development of decision-making skills }\end{array}$ & 1.86 & $21 \%$ & 1.210 & Occurs sometimes \\
\hline 11 & $\begin{array}{l}\text { Involve family's meetings at the district or city } \\
\text { level for brainstorming and decision-making }\end{array}$ & 1.82 & $20 \%$ & 1.240 & Occurs sometimes \\
\hline \multicolumn{2}{|c|}{$\begin{array}{l}\text { The practices of family partnership in decision-making as } \\
\text { a whole }\end{array}$} & 2.45 & $36 \%$ & 1.054 & Low \\
\hline
\end{tabular}

The questionnaire assigned (11) statements to determine the degree of the kindergarten practices concerning family partnership in the field of collaborating with the community and the results have been presented in Table 6 . The results indicated that there is a difference in terms of kindergarten practices concerning family partnership in the field of collaborating with the community with an average ranging from 1.60 to 3.07 between categories one and three. These results were consistent with the results of the study conducted by Sultan (2015). The statement "providing postkindergarten programs for residents of the neighborhood with the support of community institutions and volunteers" obtained the last ranking that is a low rating. 
Table 6. Mean and standard deviations of the responses of study sample on the field of Collaboration with the Community

\begin{tabular}{|c|c|c|c|c|c|}
\hline Ranking & Measure & $\begin{array}{c}\text { Arithmetic } \\
\text { Mean }\end{array}$ & $\begin{array}{c}\text { Percentage } \\
\%\end{array}$ & $\begin{array}{l}\text { Standard } \\
\text { Deviation }\end{array}$ & Evaluation \\
\hline 1 & $\begin{array}{l}\text { Contribute with community institutions in } \\
\text { national and religious events and } \\
\text { celebrations }\end{array}$ & 3.07 & $52 \%$ & 1.474 & $\begin{array}{l}\text { No specific pattern } \\
\text { of occurrence }\end{array}$ \\
\hline 2 & $\begin{array}{l}\text { Works with local organizations to provide } \\
\text { programs to enhance children's learning } \\
\text { skills }\end{array}$ & 3.04 & $51 \%$ & 1.444 & $\begin{array}{l}\text { No specific pattern } \\
\text { of occurrence }\end{array}$ \\
\hline 3 & $\begin{array}{l}\text { Offering a comprehensive family service } \\
\text { through partnership between Kindergarten } \\
\text { and counseling, health, recreational } \\
\text { organizations and others }\end{array}$ & 2.80 & $45 \%$ & 1.484 & $\begin{array}{l}\text { No specific pattern } \\
\text { of occurrence }\end{array}$ \\
\hline 4 & $\begin{array}{l}\text { Provides families with a guide to } \\
\text { community institutions to benefit from their } \\
\text { services and programs }\end{array}$ & 2.42 & $36 \%$ & 1.514 & Occurs sometimes \\
\hline 5 & $\begin{array}{l}\text { Partnerships with community institutions } \\
\text { such as libraries, parks and museums to } \\
\text { enhance the learning process }\end{array}$ & 2.36 & $34 \%$ & 1.371 & Occurs sometimes \\
\hline 6 & $\begin{array}{l}\text { Involve families in identifying and } \\
\text { benefiting from the community institutions } \\
\text { they need }\end{array}$ & 2.26 & $32 \%$ & 1.382 & Occurs sometimes \\
\hline 7 & $\begin{array}{l}\text { Al Rawda Building allows for community } \\
\text { activities that serve kindergarten's } \\
\text { objectives outside working hours }\end{array}$ & 1.80 & $20 \%$ & 1.377 & Occurs sometimes \\
\hline 8 & $\begin{array}{l}\text { Post-Kindergarten programs are offered to } \\
\text { neighborhood residents with support from } \\
\text { community institutions and volunteers }\end{array}$ & 1.60 & $15 \%$ & 1.223 & Never occurs \\
\hline \multicolumn{2}{|c|}{$\begin{array}{l}\text { The practices of family partnership in collaboration } \\
\text { with community as a whole }\end{array}$} & 2.42 & $35 \%$ & 1.051 & Low \\
\hline
\end{tabular}

The computational averages and the standard deviations associated with partnership and communicating frameworks were calculated in accordance to the Epstein's Model from the kindergarten teacher's point of view (Table 7). The overall average was 3.15 with a standard deviation of 0.869 . The practices of family partnership in the field of communicating strengthened communication between the family and the kindergarten that is consistent with the study conducted by Ratcliff and Hunt (2009). The practices of family partnership in the field of collaborating with the community came in the last ranking, with a low rating, which was different from the study conducted by (HunterJohnson, Newton \& Cambridge-Johnson, 2014). The study showed that collaborating with the community reached a degree by $77 \%$ due to the lack of mechanisms in the organizational guide for kindergartens in Saudi Arabia.

Table 7. Mean and standard deviations associated with partnership and communication frameworks from the kindergarten teacher's point of view

\begin{tabular}{|c|c|c|c|c|c|}
\hline Ranking & Measure & $\begin{array}{l}\text { Arithmetic } \\
\text { Mean }\end{array}$ & $\begin{array}{l}\text { Percentage } \\
\%\end{array}$ & $\begin{array}{l}\text { Standard } \\
\text { Deviation }\end{array}$ & Evaluation \\
\hline 1 & Parenting & 3.57 & $64 \%$ & 0.919 & High \\
\hline 2 & Communicating & 3.71 & $68 \%$ & 0.895 & High \\
\hline 3 & Volunteering & 3.02 & $50 \%$ & 1.161 & Medium \\
\hline 4 & Learning at home & 3.57 & $64 \%$ & 0.984 & High \\
\hline 5 & Decision making & 2.45 & $36 \%$ & 1.054 & Low \\
\hline 6 & Collaborating with the community & 2.42 & $35 \%$ & 1.051 & Low \\
\hline \multicolumn{2}{|c|}{$\begin{array}{l}\text { The reality of activating the frameworks of partnership } \\
\text { and communication in the light of the Epstein's model } \\
\text { as a whole }\end{array}$} & 3.15 & $54 \%$ & 0.869 & Medium \\
\hline
\end{tabular}


Independent sample t-Test was calculated to detect statistically significant difference between the average degrees of implementation of the partnership frameworks in accordance to the Epstein's (2018) model from the teacher's viewpoint. The results of t-Test have been shown in Table 8 .

Table 8. Results of the Independent Samples T-Test

\begin{tabular}{|c|c|c|c|c|c|c|}
\hline Measure & Kindergarten & Frequency & Mean & $\begin{array}{l}\text { Standard } \\
\text { Deviation }\end{array}$ & $\begin{array}{c}\text { Value } \\
\text { (T) }\end{array}$ & $\begin{array}{c}\text { Moral } \\
\text { Potential }\end{array}$ \\
\hline \multirow{2}{*}{ Parenting } & Governmental organizations & 48 & 3.55 & 0.848 & \multirow{2}{*}{-0.203} & \multirow{2}{*}{0.840} \\
\hline & Eligibility & 44 & 3.59 & 1.001 & & \\
\hline \multirow{2}{*}{ Communicating } & Governmental organizations & 48 & 3.67 & 0.879 & \multirow{2}{*}{-0.430} & \multirow{2}{*}{0.668} \\
\hline & Eligibility & 44 & 3.75 & 0.921 & & \\
\hline \multirow{2}{*}{ Volunteering } & Governmental organizations & 48 & 2.94 & 1.153 & \multirow{2}{*}{-0.633} & \multirow{2}{*}{0.528} \\
\hline & Eligibility & 44 & 3.10 & 1.177 & & \\
\hline \multirow{2}{*}{ Learning at home } & Governmental organizations & 48 & 3.58 & 0.948 & \multirow{2}{*}{0.110} & \multirow{2}{*}{0.913} \\
\hline & Eligibility & 44 & 3.56 & 1.032 & & \\
\hline \multirow{2}{*}{ Decision making } & Governmental organizations & 48 & 2.34 & 1.039 & \multirow{2}{*}{-1.062} & \multirow{2}{*}{0.291} \\
\hline & Eligibility & 44 & 2.57 & 1.068 & & \\
\hline \multirow{2}{*}{$\begin{array}{l}\text { Collaborating with the } \\
\text { community }\end{array}$} & Governmental organizations & 48 & 2.34 & 1.052 & \multirow{2}{*}{-0.773} & \multirow{2}{*}{0.441} \\
\hline & Eligibility & 44 & 2.51 & 1.055 & & \\
\hline \multirow{2}{*}{$\begin{array}{l}\text { Implementation of partnership } \\
\text { and communication } \\
\text { frameworks in the light of the } \\
\text { Epstein's model as a whole }\end{array}$} & Governmental organizations & 48 & 3.09 & 0.831 & \multirow[b]{2}{*}{-0.642} & \multirow[b]{2}{*}{0.522} \\
\hline & Eligibility & 44 & 3.21 & 0.914 & & \\
\hline
\end{tabular}

Table 8 revealed no statistically significant results for the average score of the Kindergarten practices of the family partnership in the field of parenting, communicating, and volunteering from the points of view of the Saudi kindergarten teachers. Moreover, there were no significant results obtained for average score of the kindergarten practices concerning family partnership in the field of learning at home in accordance to the Epstein's model. The value of the level of significance in the test was obtained to be 0.913 , which is a non-significant value at $(\alpha=0.01)$. There were no statistical differences between the average score of the kindergarten practices concerning family partnership in the field of decision-making and collaborating with the community with value of 0.291 and 0.441 , respectively that is a non-significant value at 0.01 .

There were no statistical differences between the average degree of implementation of the frameworks of partnership and communication as a whole in accordance to the Epstein's model from the point of view of kindergarten teachers attributed to the type of kindergarten (public or private), where the level of significance was 0.522 . The results of the second question showed that there are no statistically significant differences due to the type of kindergarten (public or private) in the reality of activating the partnership in the six fields. Kindergartens, except for some statements showed statistically significant differences in favor of private kindergartens;

1. Provide preparation programs to the child and family to facilitate the transition to primary school (e.g., visit to the child with his or her family to the school to which he intends to move)

2. Partnerships with community institutions such as libraries, parks, and museums to promote learning

An annual survey to measure the level of satisfaction for families from kindergarten showed that there are differences in favor of public kindergartens. This may be due to the process of monitoring family trends in the Kindergarten Procedural Guide supervised by the Kindergarten Council. It prepares a report on household trends including analysis, findings, and recommendations. Coleman and Hoffer (1987) described theory of parental partnership with the school, called social capital theory narrating the relationships between the family and the community, which were thought to have a strong impact on the child's performance. The study also pointed out that the lack of social capital has a negative impact on the child. Partnership in its six fields is the foundation for the child to start a strong start in his kindergarten years to be followed later at schools. 


\section{CONCLUSION}

The present study has mainly focused on the implementation of partnership framework among the Saudi kindergartens in accordance to the Epstein's model. The study results have concluded that the degree of implementation of the partnership frameworks was medium in the light of the Epstein's model. The study results have recommended providing material and moral motivation for kindergarten staff who support partnership programs with families and community institutions such as honoring the best outreach program among the kindergartens. It is also necessary to provide training programs for teachers to prepare the child for the transition from kindergarten to primary school. Moreover, schools and universities need to spread the culture of volunteering and its positive effects in kindergartens through meetings, seminars, and lectures. Activation of on-line programs facilitates communication between the family and the school and the local communities that are suitable for parents with special needs. However, the study results are limited due to the reality of implementing partnership frameworks in the light of the Epstein's model, which includes 6 fields of partnership (parenting, communicating, volunteering, decision making, learning at home, and collaboration with the community). The study was bound to a specific time period concerning only the public and private kindergartens in Jeddah, Saudi Arabia.

\section{AUTHOR INFORMATION}

Nahla M. Gahwaji, Associate professor - Childhood studies Department, King Abdulaziz University, Jeddah, Saudi Arabia,ngahwaji@kau.edu.sa

\section{REFERENCES}

Nuseirat, A., \& Biygautane, M. (2014). Training during times of financial constraints: Lessons from the case of Dubai's public sector. Policy Brief, (35).

Coleman, J. S., \& Hoffer, T. (1987). Public and private high schools: The impact of communities (Vol. 41). New York: Basic Books.

Desforges, C., \& Abouchaar, A. (2003). The impact of parental involvement, parental support and family education on pupil achievement and adjustment: A literature review (Vol. 433). Nottingham: DfES publications.

Eisenhower, A., Baker, B. L., \& Taylor, H. (2016). Starting Strong: Feasibility of an indicated prevention programme during the transition to kindergarten. Research Papers in Education, 31(4), 377-398. https://doi.org/10.1080/02671522.2015.1051100

Epstein, J. L. (2013). Ready or not? Preparing future educators for school, family, and community partnerships. Teaching Education, 24(2), 115-118. https://doi.org/10.1080/10476210.2013.786887

Epstein, J. L., Sanders, M. G., Sheldon, S. B., Simon, B. S., Salinas, K. C., Jansorn, N. R., ... \& Hutchins, D. J. (2018). School, family, and community partnerships: Your handbook for action. Corwin Press.

Hunter-Johnson, Y., Newton, N. G., \& Cambridge-Johnson, J. (2014). What Does Teachers' Perception Have to Do with Inclusive Education: A Bahamian Context? International journal of special education, 29(1), 143-157. https://doi.org/10.15362/ijbs.v21i1.250

Langford, R., Di Santo, A., Valeo, A., Underwood, K., \& Lenis, A. (2018). The innovation of Ontario full-day kindergarten educator teams: have they reproduced the split systems of care and education? Gender and Education, 30(5), 569-586.

Ministry of Education. (2016).

Nitecki, E. (2015). Integrated School-Family Partnerships in Preschool: Building Quality Involvement through Multidimensional Relationships. School Community Journal, 25(2), 195-219.

Organizational Guide for Kindergartens. (2014).

Peters. S. (2015). Ethics and Education (Routledge Revivals). Routledge, UK.

Ratcliff, N., \& Hunt, G. (2009). Building Teacher-Family Partnerships: The Role of Teacher Preparation Programs. Education, 129(3). https://doi.org/10.1080/01626620.2010.549714

Rattray, J., \& Jones, M. C. (2007). Essential elements of questionnaire design and development. Journal of clinical nursing, 16(2), 234-243. https://doi.org/10.1111/j.1365-2702.2006.01573.x

Sultan, S. (2015). Developing Teacher Training Curricula to Promote Ecological Awareness at Tertiary Education (Doctoral dissertation, National University of Modern Languages Islamabad). 